P-ISSN $2580-7781$

E-ISSN 2615 - 3238

\title{
KEBIJAKAN SISTEM RESI GUDANG DALAM PENINGKATAN PENGEMBANGAN AGRIBISNIS: TINJAUAN SECARA KONSEP, MAKSUD, TUJUAN, FUNGSI DAN MANFAATNYA
}

\section{WAREHOUSE RECEIPT SYSTEM POLICY IN IMPROVING AGRIBUSINESS DEVELOPMENT: CONCEPTUAL REVIEW, PURPOSE, OBJECTIVES, FUNCTIONS AND BENEFITS}

\author{
Sulistyaningsih \\ Fakultas Pertanian,Universitas Abdurachman Saleh Situbondo, \\ Email: lis_sulistyaningsih@yahoo.com
}

\begin{abstract}
ABSTRAK
Pertanian merupakan sektor sangat strategis dalam pengembangan agribismis di Indonesia, terdapat beberapa kendala umum permasalahan agribisnis di Indonesia terutama yang dialami petani kecil, yaitu terkait dengan pembiayaan, pemasaran, ketersediaan infrastruktur, serta intensif bagi peningkatan produksi. Fakta membuktikan, saat panen raya petani selalu dihadapkan pada turunnya harga sampai pada tingkat yang tidak menguntungkan di pasar. Tujuan dari kajian ini adalah melakukan Tinjauan secara Konsep, Maksud, Tujuan, Fungsi dan Manfaat Sistem Resi Gudang agar kebijakan ini lebih termanfaatkan oleh petani. Metode yang digunakan kajian deskriptif tentang Sistem Resi Gudang, data sekunder dengan kajian pustaka dan artikel jurnal. Hasil kajian ini kedepan digunakan untuk memperoleh rumusan keberhasilan (key success factor), dalam rangka peningkatan pemanfaatan SRG agar dapat diimplementasikan dalam skala yang lebih luas, serta menjadi referensi dalam menerapkan kebijakan SRG.
\end{abstract}

Kata kunci: Agribisnis, Sistem Resi Gudang, Fluktuasi harga

\section{ABSTRACT}

Agriculture is a very strategic sector in the development of agribusiness in Indonesia, there are several common obstacles to agribusiness problems in Indonesia, especially those experienced by small farmers, namely related to financing, marketing, availability of infrastructure, and increasing production. Facts prove, during the harvest, farmers always offer price reductions to an unfavorable level in the market. The purpose of this study is to review the Concept, Purpose, Objectives, Functions and Benefits of the Warehouse Receipt System so that this policy is more utilized by farmers. The method used is a descriptive study of the Warehouse Receipt System, secondary data with literature reviews and journal articles. The results of this study will be used in the future to obtain a key success factor, in order to increase the use of WRS so that it can be implemented on a wider scale, as well as become a reference in implementing WRS policies.

Keywords: Agribusiness, Warehouse Receipt System, Price fluctuations 
P-ISSN $2580-7781$

E-ISSN 2615 - 3238

\section{PENDAHULUAN}

Sebagai negara agraris, pertanian merupakan sektor sangat strategis bagi Indonesia. Karenanya diperlukan beragam upaya demi tercapainya optimalisasi di sektor pertanian, agar stok bahan pangan nasional mencukupi, bisa meminimalisasi impor bahan pangan, dan yang lebih penting meningkatkan kesejahteraan petani dan para pelaku usaha. Jika dikelola dengan baik dan dengan pendekatan bisnis, sektor pertanian bisa menjadi tumpuan harapan bagi kesejahteraan para petani kita. Setidaknya, sejumlah perusahaan besar terbukti mampu menangani sektor ini menjadi komoditi andalan yang sangat menggembirakan, seperti halnya keberhasilan yang telah dicapai pada bidang perkebunan tanaman keras.

Persoalan di bidang pertanian tidak saja mampu mendapatkan teknik terbaik agar sektor ini bisa secara produktif menghasilkan jumlah dan kualitas yang diharapkan dalam lahan yang kian terbatas, tapi lebih dari itu pertanian juga menghadapi kendala-kendala pembiayaan, pemasaran, ketersediaan infrastruktur, serta intensif bagi peningkatan produksi. Fakta membuktikan, saat panen raya petani selalu dihadapkan pada turunnya harga sampai pada tingkat yang tidak menguntungkan di pasar. Meskipun petani bisa menyiasatinya dengan menunda penjualan hasil panen, tapi pada saat yang sama harus dihadapkan akan kebutuhan uang tunai demi mempersiapkan musim tanam berikutnya. Selain itu, pembiayaan untuk kebutuhan hidup rumah tangga sehari-hari. Panen sering tidak menggembirakan bagi petani, karena mereka biasanya terpaksa menjual hasil panen kepada pengepul dan pedagang dengan harga murah.

Komoditi pertanian memang memiliki ciri yang spesifik, yakni berumur terbatas, dipanen pada waktu-waktu tertentu, fluktuasi harganya, serta sangat dipengaruhi harga internasional. Komoditi pertanian memiliki sistem dan mekanisme perdagangan sendiri, dan yang diperlukan adalah sistem yang bisa menyeimbangkan kepentingan konsumen dan produsen.

Sementara dari sisi pelaku usaha pertanian, tidak saja petani tetapi para Usaha Kecil Menengah (UKM), pedagang maupun eksportir, selama ini mengalami 
P-ISSN $2580-7781$

E-ISSN 2615 - 3238

sejumlah kendala dalam mengakses sumber-sumber pembiayaan. Misalnya, ketiadaan agunan aset tetap dan rumitnya birokrasi dan administrasi kredit. Bahkan jika aset tetap itu dimiliki, pihak bank sendiri seringkali tak berpengalaman dalam memberikan kredit di tingkat pedesaan. Bank dengan segala birokrasinya cenderung berhubungan dengan pelaku usaha yang telah mapan. Sementara itu akses informasi atas harga yang terjadi di pasar sangat terbatas, membuat petani menjadi pihak yang cenderung dirugikan atas tidak transparannya informasi pasar.

Sustyaningrum (2014) menyatakan, dalam menghadapi persaingan yang semakin ketat pada era globlalisasi diperlukan kesiapan dunia usaha untuk menghadapi perubahan yang sangat cepat dibidang ekonomi khususnya perdagangan. Salah satu upaya menghadapi persaingan tersebut diperlukan instrumen dalam penataan sistem perdagangan yang efektif dan efisien sehingga harga barang yang ditawarkan dapat bersaing di pasar global. Efisiensi perdagangan dapat tercapai apabila di dukung oleh iklim usaha yang kondusif dengan tersedianya dan tertatanya sistem pembiayaan dan perdagangan yang dapat diakses setiap pelaku usaha secara tepat waktu. Sistem pembiayaan perdagangan sangat diperlukan bagi dunia usaha untuk menjaminkan kelancaran usahanya terutama bagi usaha kecil dan menengah termasuk petani yang umumnya menghadapi masalah pembiayaan karena keterbatasan akses pemasaran produk dan jaminan kredit.

Listiani dan Haryotejo (2013) bahwa SRG merupakan suatu terobosan baru sebagai pembiayaan usaha bagi petani dengan jaminan komoditas yang tersimpan digudang. Selain itu dengan adanya SRG akan semakin meningkatkan produktivitas dan kualitas produk yang dihasilkan petani. Bahkan, apabila SRG dapat diterapkan dengan baik akan menjadikan manajemen usaha tani menjadi lebih tertata karena petani menetapkan strategi jadwal tanam dan pemasarannya.

Sistem Resi Gudang menjadi salah satu alternatif solusi efektif mengatasi sejumlah kendala di atas. Berkenaan hal di atas, maka urgensinya bagi kalangan petani dan UKM begitu penting dalam meningkatkan akses pembiayaan jangka pendek terutama ketika harga jual produk pertanian menurun saat musim panen. Hasil 
P-ISSN 2580 - 7781

E-ISSN 2615 - 3238

panen petani/kelompok tani bisa disimpan digudang dan sambil menunggu harga pasarnya membaik, maka resi gudang yang diterbitkan oleh pengelola gudang tertentu (yang telah mendapatkan persetujuan Bappebti) dapat dijamin kebank/lembaga keuangan non-bank untuk memperoleh kredit tanpa dipersyaratkan agunan lainnya (Bappebti, 2015).

\section{METODE PENELITIAN}

Dalam penelitian ini digunakan descriptive research atau riset deskriptif yaitu metode yang memusatkan pada pemecahan actual yang ada pada masa sekarang; sedangkan jenis data yang digunakan adalah sekunder dengan study pustaka, artikel jurnal.

\section{HASIL PENELITIAN DAN PEMBAHASAN}

Kebijakan ini diperkenalkan oleh Kementerian Pedagangan Republik Indonesia sejak diundangkannya Undang-Undang Nomor 9 pada tahun 2006 tentang Sistem Resi Gudang, untuk memberikan gambaran dan pemahamannya maka diperlukan kajian Tinjauan Secara Konsep, Maksud, Tujuan, Fungsi dan Manfaatnya Sistem Resi Gudang (SRG) dalam pengembangan agribisnis di Indonesia.

\section{Konsep Sistem Resi Gudang}

Sebuah terobosan baru telah dilakukan oleh pemerintah, dalam hal ini Kementerian Perdagangan yang melahirkan suatu sistem yang mendukung upaya pengembangan dan peningkatan kualitas komoditi. Sistem yang merupakan inovasi baru ini disebut Sistem Resi Gudang (SRG), dan telah disahkan oleh negara melalui Undang-Undang Nomor 9 Tahun 2006 tentang Resi Gudang dan telah diamandemen dengan Undang-Undang Nomor 9 Tahun 2011. Pengelolaan SRG diawasi oleh Badan Pengawas Perdagangan Berjangka Komoditi (Bappebti) yang berada dibawah Kementerian Perdagangan Republik Indonesia.

SRG dilahirkan dengan misi utama untuk meningkatkan kualitas komoditi, dan yang terpenting meningkatkan penghasilan dan kesejahteraan petani. Selain itu sistem ini mendorong petani untuk lebih profesional sehingga dapat menghasilkan komoditi 
P-ISSN $2580-7781$

E-ISSN 2615 - 3238

terbaik bahkan berkualitas ekspor. Bagi para pelaku usaha sektor agro bisnis dan agro industri hadirnya sistem resi gudang ini akan memberi kemudahan dalam memperoleh komoditi yang berkualitas, karena komoditi yang disimpan di gudang SRG telah melalui uji mutu yang dilakukan oleh satu lembaga yang disebut Lembaga Penilaian Kesesuaian.

Secara konseptual Sisten Resi Gudang dapat diaplikasikan oleh petani dengan menunda waktu penjualan hasil produksi, pada saat panen raya dimana harga cenderung turun petani dapat menunggu waktu yang tepat untuk mendapatkan harga yang lebih baik dengan cara menyimpan hasil panennya di gudang. Sistem Resi Gudang menjadi salah satu alternatif sistem pemasaran dan dapat difungsikan sebagai instrumen untuk melindungi petani dari kerugian akibat turunnya harga. Dalam konteks yang lebih makro Sistem Resi Gudang tidak saja membantu petani terhindar dari kerugian akibat jatuhnya harga, namun juga dapat dijadikan sebagai instrumen untuk menjaga stabilitas ketersediaan pangan dan ketahanan pangan nasional.

Dengan demikian Sistem Resi Gudang tidak hanya mampu meningkatkan kesejahteraan petani, tetapi juga dapat meningkatkan perekonomian wilayah secara luas. Melalui Sistem Resi Gudang sebenarnya akan membiasakan petani bahkan mendorong petani dan pelaku lain dalam agribisnis untuk menghasilkan produk yang memenuhi standar mutu. Namun implementasinya masih mengalami banyak kendala yang mengakibatkan Sistem Resi Gudang belum beroperasi secara maksimal.

\section{Maksud Sistem Resi Gudang}

Pembiayaan merupakan salah satu masalah yang seringkali dihadapi oleh para pelaku usaha terutama petani dan usaha kecil menengah. Pada musim panen, petani menghadapi fenomena turunnya harga komoditi yang tajam. Kondisi ini sangat merugikan para petani, karena mengakibatkan:

a) Petani tidak dapat menutupi biaya produksi dan biaya tanam kembali;

b) Petani tidak dapat memenuhi kebutuhan hidupnya.

Kondisi turunnya harga jual yang tajam dapat diatasi antara lain dengan melakukan sistem tunda jual. Namun, sistem tunda jual tidak dapat dilakukan secara 
P-ISSN 2580 - 7781

E-ISSN 2615 - 3238

mandiri oleh petani, sebab hasil panen merupakan sumber penghasilan satu-satunya yang dimiliki oleh petani untuk memenuhi kebutuhan hidup dan memulai proses produksi yang baru. Persoalan-persoalan tersebut diatas selalu melanda petani, dan untuk meningkatkan pendapatan petani, maka diperlukan upaya terobosan peningkatan harga gabah, salah satu alternatif yang dilakukan adalah melalui penyimpanan gabah, hal ini dimaksudkan untuk menunda penjualan pada saat panen raya. Peningkatan harga jual gabah atau beras terjadi akibat mekanisme permintaan dan penawaran pasar, dimana pada jangka waktu tertentu setelah panen raya akan terjadi peningkatan permintaan. Pada fase tersebut harga jual akan meningkat, dan diharapkan dapat meningkatkan pendapatan petani padi.

Alternatif penyimpanan gabah sebagaimana termaksud diatas harus didukung oleh mekanisme pembiayaan atau kredit bagi petani. Untuk mengatasi masalah ini, pemerintah Indonesia melalui Kementerian Perdagangan menciptakan salah satu alternatif solusi pembiayaan bagi petani yaitu Sistem Resi Gudang (SRG) yang telah disahkan oleh pemerintah. SRG merupakan suatu sistem pembiayaan yang disediakan oleh pemerintah untuk melindungi petani terutama pada masa musim panen. SRG membantu petani untuk melakukan tunda jual sehingga petani tidak menderita kerugian pada saat harga jual turun tajam(Puska Dagri, BP2KP, Kemendag, 2015).

Adanya Sistem Resi Gudang dimaksudkan membantu dan member dayakan petani dalam hal menyiasati terhadap kesulitan pembiayaan. SRG merupakan instrument penting bagi petani untuk memperoleh kredit dari bank dan lembaga keuangan non bank, dengan tingkat nilai bunga yang rendah.

Senada dengan Ashari (2011) maksud SRG adalah menciptakan sistem pembiayaan perdagangan yang diperlukan oleh dunia usaha terutama usaha kecil dan menengah termasuk petani. Selain itu UU SRG dimaksudkan untuk memberikan kepastian hukum, menjamin dan melindungi kepentingan masyarakat, serta mampu menciptakan iklim usaha yang dapat lebih mendorong laju pembangunan nasional. 
P-ISSN 2580 - 7781

E-ISSN 2615 - 3238

\section{Tujuan Sistem Resi Gudang}

Tujuan jangka pendek resi gudang yaitu agar petani bisa mendapatkan akses kredit secara cepat dengan bunga rendah, petani juga bisa menggunakan fasilitas resi gudang ini untuk mendapat pendanaan, di mana pada saat harga turun petani juga dapat melakukan tunda jual sehingga petani bisa menikmati harga yang lebih baik pada saat harga sudah mulai meningkat kira-kira 2 atau 3 bulan setelah panen selesai.

Dalam jangka panjang petani dapat memproduksi hasil-hasil pertanian yang berkualitas tinggi, berstandar, juga diharapkan petani makin sejahtera dan menjadi petani pengusaha.

\section{Fungsi Sistem Resi Gudang}

Dengan adanya Sistem Resi Gudang, akan terbuka peluang bagi petani untuk:

a. Mendapatkan harga jual yang lebih baik, dengan cara menyimpan komoditi di gudang terlebih dahulu saat panen raya di mana harga umumnya rendah, kemudian menjualnya ketika harga tinggi.

b. Mendapatkan kepastian mutu dan jumlah, karena test uji mutu dilakukan oleh LPK yang telah terakreditasi.

c. Mendapatkan pinjaman dari bank untuk pembiayaan modal kerja pada musim tanam berikutnya dengan jaminan Resi Gudang tanpa agunan lainnya.

d. Mempermudah jual-beli komoditi secara langsung maupun melalui Pasar Lelang karena tidak perlu membawa komoditinya sebagai contoh, tetapi cukup membawa Resi.

e. Mendorong petani untuk berusaha secara berkelompok sehingga meningkatkan efisiensi biaya dan posisi tawar petani.

\section{Kemanfaatan Sistem Resi Gudang}

\section{a. Petani produsen}

- Mendapatkan harga yang lebih baik (menunda waktu penjualan).

- Kepastian kualitas dan kuantitas atas barang yang disimpan, karena test uji mutu. 
- dilakukan oleh LPK yang telah terakreditasi.

- Mendapatkan pembiayaan dengan cara yang tepat dan mudah.

- Mendorong berusaha secara berkelompok sehingga meningkatkan posisi tawar.

- Mempermudah jual-beli komoditi secara langsung maupun melalui Pasar. Lelang karena tidak perlu membawa komoditinya sebagai contoh, tetapi cukup membawa Resi.

- Mendapatkan pinjaman dari bank untuk pembiayaan modal kerja pada musim tanam berikutnya dengan jaminan Resi Gudang.

\section{b. Pergudangan}

- Mendorong tumbuhnya industri pergudangan dan bidang usaha terkait.

- Mendapatkan income dari jasa pergudangan.

\section{c. Perusahaan pengguna komoditi /processor}

- Meningkatkan akses untuk mendapatkan sumber bahan baku yang berkualitas.

- Mengurangi biaya penyimpanan.

- Perencanaan supply yang lebih baik.

\section{d. Pedagang/Eksportir}

- Ketersediaan atas volume dan kualitas.

- Supply tersedia sepanjang musim.

- Terdapatnya pembiayaan bagi perdagangan (ekspor) Resi Gudang sebagai dokumen transaksi Letter of Credit akan menambah keyakinan para pihak termasuk bank (issuing bank \& nominated bank).

- Mencegah/mengurangi terjadinya fraud (penipuan) dalam transaksi ekspor.

\section{e. Pelaku Usaha}

- Mendapatkan jaminan kepastian mutu dan jumlah atas komoditas yang mereka perdagangkan. 
- Mendapatkan suplai komoditas yang lebih pasti, karena dapat diketahui secara pasti jumlah komoditas yang tersimpan di gudang.

- Mendapatkan pinjaman berulang (revolving loan) dari bank untuk modal kerja. Dengan jumlah modal kerja yang sama, akan dapat diperoleh omzet perdagangan yang lebih besar dengan cara meminjam dari bank atas jaminan Resi Gudang.

\section{f. Perekonomian Daerah/Nasional}

- Mendorong tumbuhnya pelaku usaha (petani produsen/eksportir), industri pergudangan, jasa perbankan, jasa asuransi, jasa pengujian mutu, dan lainlain di daerah.

- Sarana pengendalian sediaan (stok) nasional yang lebih efisien.

- Meminimalisir adanya praktek penimbunan gabah, jagung oleh pedagang pengepul.

\section{g. Perbankan/Lembaga Keuangan Non-Bank (LKNB)}

- Tumbuhnya peluang baru, jasa perbankan di daerah (Propinsi \& Kabupaten).

- Perlindungan yang tinggi atas jaminan.

- Jaminan bersifat liquid.

- Aktivitas penyaluran kredit yang aman dan menguntungkan.

- Pengenalan dan pemanfaatan produk perbankan bagi petani/UKM berupa kredit resi gudang serta produk perbankan lainnya (tabungan, deposito dll).

- Pembiayaan transaksi dalam negeri dan ekspor (L/C) (anonimous, 2014)

\section{h. Manfaat Lain Sistem Resi Gudang}

- Memperkuat daya tawar petani serta menciptakan efisiensi didunia agrobisnis, dimana petani bisa menunda penjualan komoditas setetah panen, sambil menunggu harga komoditi membaik kembali dengan menyimpan hasil panen mereka digudang-gudang tertentu yang memenuhi persyaratan.

- Dengan tersedianya Sistem Resi Gudang akan memungkinkan bagi pemilik resi gudang untuk meminjam diluar negeri yang bunganya lebih rendah 
terutama pinjaman dengan jaminan resi gudang komoditas eksport. Dengan cara demikian dapat dilakukan perlindungan terhadap nilai tukar valuta asing yang menjadi praktek ini dilakukan di Kenya dan Uganda dimana sediaan kopi sering kali digunakan sebagai pinjaman dalam mata uang Poundstering.

- Resi gudang dapat digunakan bagi petani dalam membiayai proses penanaman dan jugabagi pabrikan dapat digunakan untuk membiayai persediaan bahan baku. Apabila terjadi cedera janji atas suatu kewajiban yang dijamin dengan resi gudang tersebut, misalnya pinjaman bank maka pemegang resi gudang memiliki hak utama atas komoditas acuan atau nilai yang setara dengan nya.

- Mobilisasi kredit ke sektor pertanian. Adanya kepastian jaminan dari pihak gudang tertentu yang telah disetujui oleh institusi tertentu memberikan keyakinan bagi pihak bank untuk memberikan pinjaman alas jaminan resi gudang tersebut kepada para petani atau pedagang yang menyimpan barangnya di gudang tersebut.

- Resi gudang dapat digunakan untuk mendapatkan dana cas untuk perdagangan berjangka pada bursa berjangka yang ada sehingga meningkatkan nilai kompetisinya.

- Resi gudang dapat dijadikan instrumen kontrak serah yaitu apabila pada suatu transaksi terjadi kesepakatan untuk melakukan penyerahan barang pada suatu masa mendatang yang ditentukan maka resi gudang ini dapat dijadikan suatu bentuk kontrak serah yang penyerahan barangnya dilakukan dengan sistem yang diatur dalam perdagangan berjangka.

- Memperkecil fluktuasi harga dimana petani tidak perlu menjual barangnya segera setelah panen yang biasanya harga sangat rendah (penjualan terpaksa). Dengan menahan barangnya beberapa waktu diharapkan harga menjadi lebih baik. 
- Mengurangi risiko dipasar-pasar produk pertanian, memperbaiki sistem pengamanan pangan dan terbukanya akses kredit bagi pedesaan.

- Mendorong memperbaiki mutu dan transparansi bagi industri pergudangan karena harus mematuhi peraturan tertentu dan dilakukan pengawasan.

- Membantu menciptakan pasar-pasar komoditas atas dasar persaingan, informasi pasar dan perdagangan internasional.

- Mengurangi ketergantungan terhadap pemerintah dalam perdagangan produk pertanian.

- Memperkecil kerugian selelah panen karena sistem penyimpanan yang baik.

- Biaya transaksi menjadi lebih murah karena jumlah dan mutu komoditas yang ditransaksikan telah terjamin.

- Meningkatkan kesadaran pentingnya mutu yang baik bagi para pihak yang terkait dengan usaha komoditas pertanian.

Secara Konsep, Maksud, Tujuan, dan Fungsi Sistem resi Gudang sangat baik untuk kepentingan petani utamanya dalam mengatasi persoalan harga yang fluktuatif dan pebiayaan usahatani namun beberapa kajian pustaka dan artikel jurnal masih terdapat beberapa kendala yaitu belum optimalnya implementasi SRG di Indonesia antara lain, kurangnya pemahaman tentang SRG dan manfaatnya bagi pelaku usaha misal petani, kelompok tani dan lain-lain.

Untuk mendapatkan solusi dari permasalahan implementasi SRG, diperlukan program terstruktur yang menjadi komitmen dari seluruh pelaku (stakeholder) SRG (petani, pemerintah, lembaga keuangan/bank dengan harapan meningkatkan pemanfaatan SRG di Indonesia, sehingga kedepan diperoleh rumusan keberhasilan (key success factor) dan rekomendasi kepada stakeholder SRG dalam rangka peningkatan pemanfaatan SRG agar dapat diterapkan dalam skala yang lebih luas sehingga menjadi referensi dalam menerapkan kebijakan SRG untuk meningkatkan pembiayaan pertanian. Di samping itu, untuk mendapatkan strategi dalam rangka 
P-ISSN $2580-7781$

E-ISSN 2615 - 3238

memperkuat komitmen para pelaku dalam rangka meningkatkan pemanfaatan SRG (anonymous, 2020).

\section{KESIMPULAN}

Secara konsep, maksud, tujuan, fungsi, dan manfaat Sistem Resi Gudang sudah sesuai dengan Undang-Undang SRG tetapi penerapanya dalam pengembangan agribisnis petani belum sepenuhnya melaksanakan secara optimal, petani masih belum menikmati hasil secara maksimal.

\section{DAFTAR PUSTAKA}

Anonymous, 2014 Analisis Implementasi Sistem Resi Gudang Komoditi Lada, Pusat Kebijakan Perdagangan Dalam Negeri. Jakarta.

Anonymous, 2020 https://www.bi.go.id/id/umkm/penelitian/Pages/Kajian-danPublkasi-Sektor-Riil.aspx, 23 Nopember 2020.

Ashari (2011), Potensi Dan Kendala Sistem Resi Gudang Untuk Mendukung Pembiayaan Pertanian Di Indonesia, Forum Penelitian Agro Ekonomi, Volume 29 No 2, Desember 2011:129-143. Bogor.

Badan Pengawas Perdagangan Berjangka Komoditi (Bappebti). 2015. Kementerian Perdagangan Republik Indonesia.

Listiani Nurlia. Haryotejo B. 2013. Implementasi Sistem Resi Gudang Pada Komoditi jagung: Studi Kasus Di Kabupaten Tuban Propinsi Jawa Timur. 2013. Buletin Ilmiah Litbang Perdagangan.Vol 7 Nomor 2.Desember 2013.

Pusat Kebijakan Perdagangan Dalam Negeri-Badan Pengkajian dan Pengembangan Kebijakan Perdaganan (Puska Dagri, BP2KP) Kementerian Perdagangan. 2015. Analisis Kesiapan Sistem Resi Gudang Dalam Mendukung Ketahanan Pangan.Jakarta

Sustyaningrum Evi. 2014. Eksistensiresi gudang sebagai lembaga jaminan di Indonesia, Rertorium, ISSN, 2356-2646 Volume 1 No 2, Nopember 2014. Solo: UNS.

Undang-Undang Republik Indonesia Nomor 9 Tahun 2006. Sisten Resi Gudang.14 Juli 2006. Lembaran Negara Republik Indonesia Tahun 2006 Nomor 59. Jakarta. 